\title{
Alpha-thalassemia-intellectual disability syndrome linked to chromosome 16
}

INSERM

\section{Source}

INSERM. (1999). Orphanet: an online rare disease and orphan drug data base. Alphathalassemia-intellectual disability syndrome linked to chromosome 16. ORPHA:98791

Alpha-thalassemia-intellectual deficit syndrome linked to chromosome 16 (ATR-16), a contiguous gene deletion syndrome, is a form of alpha-thalassemia (see this term) characterized by microcytosis, hypochromia, normal hemog lobin ( $\mathrm{Hb}$ ) level or mild anemia, associated with developmental abnormalities. 